\title{
THE FOOD OF THE DOGFISH, SCYLIORHINUS CANICULUS L.
}

\author{
By Nellie B. Eales, D.Sc. \\ Zoology Department, University of Reading
}

During the past eight years records have been kept of the contents of the stomachs of all dogfish dissected in the Zoology Department of Reading University. The specimens, numbering about 450 altogether, came from Swansea Docks, and were caught off the west coasts of the British Isles. Students were asked to spread out the contents of the stomach of the fish they were dissecting in a dish, and to make notes of those animals they could identify. I then, as far as was possible, checked the identifications, and removed for more detailed investigation any specimens of particular interest. In the circumstances it was impossible to make accurate numerical records of each species, or to work out fragments from partially digested material, but the rare specimens were recorded by numbers. Sometimes a record of one means one perfect specimen.

The records showed a remarkable uniformity, indicating either a habit on the part of the fish of hunting over certain bottom areas, or a selective search for palatable food. Six phyla were represented, and despite partial digestion, the genus and sometimes the species could be determined. Details are given in Table I.

Comparing these records with those of Ford (I92I), there is a close resemblance in the nature of the food, allowing for variations due to the location of the feeding grounds. Several points of interest may be noted:

(i) Fish comprise only a part of the food of the dogfish and consist of small specimens. As Ford points out, dogfish are bottom feeders, and the presence of pelagic fish in the stomach is largely accidental.

(ii) Ford's records do not include the horse mackerel, which in my records for I948 and 1949 were almost as numerous as herring. The scutes on this fish retard digestion and it is therefore easy to identify.

(iii) In the Invertebrate groups we have many records in common-some of relatively rare animals, e.g. Atelecyclus and Gonoplax, and others indicating a selective feeding habit, e.g. Upogebia, Thyone, Gephyrean worms.

(iv) Molluscs, except for Buccinum, are not well represented. How does the dogfish tackle a whelk? Does it swallow it whole, and dissolve the shell? I have found lamellibranch shells and even cuttlebone undigested, but have never seen a trace of a whelk shell, though opercula are frequently found. Are the opercula scooped up from dead material on the sea bottom?. Similarly, 
does the dogfish swallow the shell containing the hermit crab-for again, no trace of the shell remains, though the crab itself forms a large proportion of the food in some fish?

\section{TABle I. SPecies ReCorded From Stomachs of Scyliorhinus caniculus}

Phylum Chordata: class Pisces

$\begin{array}{llllllll}\text { I942 I943 I944 I945 I946 I947 } & \text { I948 } & \text { I949 }\end{array}$

Clupea harengus (6 or more records)

Trigla lucerna

Limanda limanda

Cottus bubalis

Caranx trachurus

Nerophis lumbriciformis

Egg capsule of dogfish

Phylum Annelida: Chaetopoda, Polychaeta Aphrodite aculeata

Nereis sp.

Nephthys sp.

Glycera lapidum?

Lumbriconereis latreilli

Phylum Gephyrea

Phascolosoma sp.

Phylum Echinodermata: class Holothurioidea Thyone fusus

Phylum Arthropoda: class Crustacea Hippolyte varians

Leander serratus

Crangon vulgaris

Homarus vulgaris (small)

Nephrops norvegicus

Galathea spp.

Upogebia stellata

Eupagurus bernhardus (many)

Portunus, mainly depurator

Atelecyclus septemdentatus

Gonoplax rhomboides

Phylum Arthropoda: class Pycnogonida Pycnogonum littorale

Phylum Mollusca: class Lamellibranchia Mya truncata (siphons)

Ensis ensis (shell and siphons)

Phylum Mollusca: class Gastropoda Buccinum undatum (opercula)

Phylum Mollusca: class Cephalopoda Sepia officinalis - small

Loligo forbesii Octopus (acetabula) beaks of adults

(v) There is no mention of Nephrops norvegicus in Ford's records. This is not surprising, for his fish came from the English Channel where there are none of the extensive muddy bottoms which these lobsters require. In fact, Nephrops is not recorded in the Plymouth Fauna list. In my records, it appeared for the first time in 1948 , and in 1949 was abundant. I wrote to the fish merchant from whom the fish were obtained, asking for information 
concerning the fishing grounds. He replied that only during the past two years had the usual grounds, closed on account of mine fields during the war, been re-opened. Recently fish had been caught in the Irish Sea and off the extreme west coat of Ireland, to a distance of 400 miles west of Swansea. Muddy areas are present to the north and west of the British coasts, and the dogfish were evidently feeding on these grounds.

Collating the above information, it appears that the favourite food of the dogfish consists of a mixture of whelks, shrimps, hermit crabs, cuttlefish, Thyone, and small fish of various species. They are general feeders on benthic and pelagic animals, scooping some up from the bottom and catching others while swimming. There is no evidence that they are a serious danger to the food fishes.

\section{REFERENCE}

FoRD, E., I92I. A contribution to our knowledge of the life histories of the dogfishes landed at Plymouth. Fourn. Mar. Biol. Assoc., Vol. xII, pp. 468-505. 